\title{
John Smith's: Historical perspectives and historical precedence
}

Simon Frost, Bournemouth University

Stephen Hall, University of Glasgow

\begin{abstract}
This companion piece to 'Bespoke Bookselling for the twenty-first century: John Smith's and current UK higher education' (also in this issue of Book 2.0) provides a historical narrative of the bookshop chain John Smith's. From its emergence in Glasgow in the 1750s, through its negotiation of the Net Book Agreement around 1900 and its strategies for survival and growth after the agreement's collapse in the digital era, the article provides the only comprehensive history of this unique book retail business up to the present day. What is apparent is that its current diverse business model has a clear historical precedence. Their business involvements have included publishing, circulating libraries, library and learning material supply, creation of cultural events, transitioning from local to global and, especially, cooperation with higher education. John Smith's is a perfect example of how bookselling was and is far more than simply the activity of selling books.
\end{abstract}

\section{Keywords}

John Smith's; Glasgow; bookshop; retail; Glasgow Cookery Book; Net Book Agreement; higher education; library supply. 
In constructing a brief history of the bookshop chain John Smith's, what becomes apparent is the constant pull between diversity and consolidation, undertaken in response to periods of liberalization and regulation. John Smith opened his first bookshop, in Glasgow, in 1751. ${ }^{1}$ Coming from a background of wealth, John Smith had been variously a bookbinder, saddler and soldier before returning to the book trade in 1751 and establishing Glasgow's first circulating library by 1753 that, extant evidence suggests, was its primary business, in conjunction with publishing and retail activities - standard practice in the book trade prior to greater divisions of trade labour around the turn of the eighteenth to nineteenth century. A third move to premises in Trongate, in 1763, established Smith's at the commercial centre of Glasgow, during a period of wealth-driven expansion from the tobacco (and thus slave) trade - indeed much of the Smith clan was involved in West Indian and American trade. In addition, the University of Glasgow, Scotland's second oldest university, was emerging as a seat of the Scottish Enlightenment, itself a print-driven phenomenon; enlightenment thinkers 'made print the very pulse of their daily lives' (Brown 2012: 348). Adam Smith was appointed Professor of Logic at the University; major advances in science were being created by the likes of William Cullen and Joseph Black, and, with local type founding (Alexander Wilson of Calmachie, who later became Professor of Astrology) and printing (Robert Urie and Bros. Foulis), Glasgow was 'sending out the finest books in Europe alike in scholarship and typography' (John Smith and Sons 1925: 12). This historical context underpins a sense that, from its beginnings, John Smith's (forthwith referred to as JS) was responding to technological, educational and commercial opportunities by becoming a successful retail wing of an enlightenment project in an early industrialized environment.

In earlier centuries, general-trade bookselling could differ markedly from the image of the dedicated bookstore. The nineteenth century had the private circulating library (the largest included Mudie's, W. H. Smith's and Boot's), where distribution, both local and nationwide, took place 
through a system equivalent to hire purchase (especially suitable for multi-volume novels of the period), with the shop also providing a social meeting space for readers. ${ }^{2}$ Between 1763 and 1829 , the JS business expanded, with two further John Smiths, a son and a grandson, taking the helm. The third John Smith, who used the signature 'John Smith Youngest' long after his father and grandfather had died, expanded the bookselling business through his network of university and merchant friends. The circulating library too still the core business, was continually grown to become the largest in Glasgow, containing at least 10,000 volumes by 1810 rising to 20,000 two decades later - aptly named the Glasgow Circulating Library. Subscribers were charged ‘ $£ 3.3$ s per year; $£ 1.15$ s half year; $£ 1.1$ s quarter; 10 s.6d per month - [who] can borrow 10 volumes at a time in town, 24 in the country' (Cleland cited in Hall 2009: 53). Subscription worked for readers by spreading costs, and for booksellers by binding readers into longer-term agreements, tying the reader to books supplied solely by the library - a strategy of, partly, tying purchasing funds to Smith's services that would appear again with ASPIRE. The circulating library system in general and the informal regulation of costs that it encouraged worked against liberalization of the book trade but, for better or for worse, it also introduced stability during its more-than-a-century lifetime.

Publishing was another of Smith's diversified activities, most often co-publishing with Edinburgh and London booksellers to share costs, including Longman's, Blackwood, Brash, Constable, Hatchard and Collins. At least 643 titles have been identified with the Smith and Sons imprint, not including catalogues and multiple editions of the same title, from Thoughts on Universal Peace (Thomas Chalmers, 1816) to Restoring Scotland's Castles (Robert Clow, 2000). Much of the nineteenth-century output at John Smith's publishing peak was religious, but given that Glasgow was one of the Scottish centres for religious discourse and, as Simon Eliot has clarified, the dominant genre of the nineteenth century was religious works, this comes as little surprise. ${ }^{3}$ 
Although the market was dominant, John Smith's output was not limited to religious pamphlets. The expanding population and increased numbers of schools and university classes led the company to expand their textbook range by the 1830s, with dictionaries and various grammars for French, English and Greek. JS at this time had moved to the newly built Hutchieson Street, about a ten-minute walk from High Street. With most of the retail area clustered half a mile west of High Street where the College or University was situated, the students had a great choice. Between 1824 and 1834 there was an average of 27 booksellers, with a further 25 that had bookselling as a secondary business. Despite, or perhaps because of, the competition, John Smith's were able to publish the Glasgow University Album between 1826 and 1838, containing prose, poetry and articles written by the students.

When John Smith the youngest died in 1849, the company spent two decades in the hands of a partner, David Watson and his son, and then was transferred to Watson's partner, John Knox (d. 1889), before passing to John Knox's son David Knox (1867-1927). It was David Knox, wanting to make his assets easily accessible in the event of his death, who turned John Smith's into a private limited company in 1908, providing shares for investors and protecting his assets, and giving it the name it would trade with for the rest of the century, John Smith \& Son (Glasgow) Limited. Prior to forming the limited company, trading figures for 1889 were total sales of $£ 24,973$ with trading profit of $£ 628$. In 1909 , after the change, total sales was $£ 35,711$, with trading profit of $£ 997$, and in 1910 the total sales was $£ 35,881$, with a trading profit of $£ 1203$, with profits continuing a moderate rise thereafter. ${ }^{4}$

The late nineteenth century was not an easy time for booksellers, particularly before the Net Book Agreement prevented heavy discounting on new books, and many booksellers struggled to survive. JS countered some of this by establishing themselves as agents to publishers in supplying books. Their links with the law publishers T. \& T. Clark and William Greens of Edinburgh meant 
they were the sole suppliers of law books in the city; they published the journal for the Scottish Institute of Accountants from their base in Renfield Street, but, although their publishing became more science and technical oriented, their religious publishing still continued with a close association with the religious publisher Gardner Hitt of Edinburgh. With the exception of fiction, John Smith's' publications followed trends recognized by Eliot for education, medicine and law (1994: 44). In the twentieth century too JS published to the markets it knew best, publishing numerous bespoke textbooks, including The Glasgow Cookery Book, popularly known as the 'purple book', in multiple editions from 1951 to 1975 , becoming the standard book for the domestic classes in schools, instructing in traditional Scottish dishes, and selling over 31,000 copies in Glasgow. At JS, the conflux between retail and publishing to the same market has a long heritage.

In addition to publishing textbooks, JS were actively involved with promoting education. Their educational guide, published in 1908 for the coming academic year, covered various public and private educational institutions, providing prospectuses of these institutions for the whole of the United Kingdom and the continent. The adverts within the publication identified JS as the supplier not only of books but of all equipment needed for students to be successful. This was an important component of marketing that was also used when they were the named distributors of the UCAS entrance guides for Scotland, with a full-page advert on the inside rear cover next to the student booking form (1908-1909; COSHEP 1999).

Up until the late 1960s, selling and business practices at JS were based on traditional methods perfected over a very long period. Under the managing directorship of Robert Clow, however, from 1969 (Anon. 1994), JS experienced a measure of innovation. In the words of his successor, Willie Anderson, 'Robert [...] had ideas that were probably ahead of their time as far as bookselling was concerned. He had an ambition for John Smith's and its position in Glasgow society [...] and a quality of bookselling that could be brought to Glasgow' (McCleery et al. 2009: 
43). The St Vincent Street shop was to become the iconic bookselling landmark in Glasgow with six floors of books dedicated to a wide range of subjects, Ordinance Survey and HMSO. JS were one of the earliest users of electronic stock control and book ordering, had the largest selection of fiction outside of London, were the first bookshop to launch author evenings in 1979 with authors such as Lauren Bacall and David Attenborough, and held lunchtime musical recitals (McCleery et al. 2009: 48). They were also the first to open a multimedia department in the early 1990s dedicated to selling CD-ROMs. Robert Clow believed that staff should own the company they worked in, and so introduced the means whereby staff could become shareholders.

When Robert Clow retired in 1994, the managerial experience at JS was able to maintain its wider impact within the bookselling trade through Willie Anderson, who went on to become president of the Booksellers Association from 1995 until 1997, and then president of Book Tokens Ltd in 2009. It was Anderson who initiated the opening of a JS branch in Seattle in the United States to increase book delivery and improve costs. Eventually, Anderson was made Deputy Chairman of JS when the company was acquired by its current CEO, Peter Gray, after 2001, and was awarded the Gerry Davis Award for services to bookselling in 2008.

\section{Diversification}

Before the Net Book Agreement (NBA est. 1901), what we might now call 'designated bookshops' would customarily offer stationery, leather and fancy goods, correspondence and visiting cards, alongside books and other items. Drapery shops, similarly, sold books as part of their business of 'good taste' (Anon. 1906: 33-34). From Smith's eighteenth-century circulating library catalogues, we can see they sold other 'beneficial' or curative products besides books, such as Rowley's Herb Snuff and Tobacco, and Swede's tea. The company's Short Note on a Long History from 1925 still describes Smith's as Booksellers, Publishers and Stationers, and stationery is still a strong line 
today. Diversity in general bookselling thrived too throughout the twentieth century. The diversified stock of W. H. Smith's sold convenience, or, when incorporating the first Penguin paperbacks, Woolworth's sold affordable luxury. Indeed, by the 1960s, the authority that paperbacks were slowly acquiring allowed JS to temporarily transform one of its newly acquired properties (the Stenhouse shop) into an outlet for Penguins and other paperbacks, around 1967. And in the 1970s, the company used one of its Glasgow retail shops - a property that was proving hard to sell - as an antiques business on its ground floor, while the basement became a snack bar, trading as 'Go Lightly' and selling, as Clow put it, 'good substantial and wholesome food/salads on the selfservice principal' (1972).

The NBA, however, encouraged a business model based near-exclusively on book retail that persuaded some to think of books in isolation, rather than of their role in a larger delivery system alongside other purchasable items. The NBA, when it introduced controls against discounting, limited the opportunities for a liberalization of the overall market, and concurrently encouraged the specialist book-centred retail chain. Post NBA in the mid-1990s, the field was opened to (and opened by) larger retail chains, such as Borders, Waterstone's and Dillons, all but a few of which have now disappeared. These chain retailers assumed that, with the loss of the NBA, they would make up their revenue difference through backlist sales, but the arrival of supermarkets to bookselling undermined that model, and such chains collapsed. Meanwhile, the supermarkets (national giants such as Sainsbury's and Tesco's) sold discounted books alongside groceries and electrical appliances and, with the almost boundless virtual 'stock' of online retail, the book market has again diversified. In such a market, therefore, it may not be so surprising to find JS selling hard hats and surveying equipment alongside textbooks, in the context of vocational academic supply.

It should be noted, however, that an exception to the NBA was made for public libraries, the rules for which were clarified in 1929. This was when JS began to develop its library supply 
business. In a legislative circumvention, university libraries could declare themselves open to the public and thereby gain exemption too from the NBA and thus qualify for additional discounts. By 1971, John Smith's opened its University Library Department, which would go on to supply university libraries in Europe, South Africa and East Asia, winning a tender in 1996 to supply all British Council libraries worldwide. The central offices of JS and their library supply were run from a converted church in Kent Road in Glasgow. All the shops were linked by a computer network, which had been set up in the 1980s and linked to improve book supply to customers. In the 1990s this system also had a full list of UK 'Books in Print' and access to the equivalent in the United States.

However, with the collapse of the NBA, the market changed. Libraries could form buying syndicates to force greater discounts, reducing margins and increasing competition. This left JS to cope as best it could until becoming a separate company under Coutts Information Services after 2001. That the NBA was restrictive and worked against liberalization was true, but the counterbalance was its ability to promote stability. Similarly, whether or not the freed library market provided immediate benefits for readers through greater access to titles is open to question. But if the concern is for a book delivery system as a whole, what follows is that the loss of stability took with it the infrastructural benefits available through long-term planning: itself a factor that reappears now in the context of longer investment-and-return periods for smart card, data-driven bookselling.

Concurrent with the collapse of the NBA came the rise of online book retail typified by Amazon, coming online in 1995 as a bookseller, then rapidly diversifying as the market opened beyond recognition. Unencumbered by the factors facing bricks-and-mortar shops - rates and other costs linked to premises, comparable staffing costs, limitations on storage capacity and shopping hours - and buoyed by opportunities from near-limitless virtual storage and print-on-demand 
technologies encouraging the now-famous 'long tail', online bookstores could force retail prices to levels that other bookselling operations simply could not match. To a certain extent, the online (Amazon) book price, although fluctuating, has come to represent a bottom line to be beaten, or risen above only with caution and added value.

With the sudden pressure on high street book retail from online and large-chain retail, JS suffered. In 1998, its profits had decreased to $£ 71,000$, half that of its previous year. Redundancies followed, and by 2000 the company had all but abandoned its other operations to concentrate on academic bookselling and world-market library supply (developed since 1929). Following a buy-up of all John Smith's shares by Coutts Information Services in 2001, the library supply business separated under the Coutts name, leaving the company with additional, formerly Coutts-owned outlets in England and, in 2003, Ireland, along with one in Botswana, squarely in the business of academic bookselling.

\section{John Smith's relationship with higher education, in Glasgow and beyond}

John Smith's had long targeted the student community, but in 1907, partly in response to the various relocations of the University and establishment of colleges around Glasgow, they opened a new technical bookshop at 195 George Street, opposite the Glasgow and West of Scotland Technical College. In 1913, a further branch was opened at 28-30 Gibson Street, for the main University at Hillhead, and in 1915 a shop at 10 University Avenue.

Figure 1: Advertisement for John Smith \& Son (Glasgow), booksellers, in Glasgow University Magazine, 18 October 1922 - note the date for 'established', 1742, since John Smith I was not 
discharged from the Army until 1747. Although there is evidence of book trade activity dating from 1747, JS as a continuous trading business only began in 1753.

Just before World War I they had acquired Alex. Stenhouse at 56 Bank St., another bookseller supplying to students. John Smith's chose to retain the Stenhouse name and became the primary source for medical texts and equipment for medical students, including the manufacture of Klinöstic diagnostic instruments, until Japanese plagiarism undercut the market in the 1960s (Clow 1972). Further university-linked shops came and went, and at the end of the 1960s both the University of Glasgow and the now University of Stirling approached JS about opening a dedicated student shop on their premises. At Stirling this was in the MacRobert Centre, and in Glasgow the John McIntyre Building, moving to its current location in the Fraser Building in 2009.

Towards the end of the twentieth century, JS were combining their general bookselling in Glasgow with extensive university bookselling throughout Scotland: in all the main Glaswegian university campuses - Glasgow (1969), Strathclyde (1994), Glasgow Caledonian (1994), Paisley (1994) and Jordanhill (1994) - and in Stirling University (1969) and Dundee (1994). They had a number of shops, including campus shops in Jordanhill, Bell College, Craigie, and general shops in Glasgow at St. Vincent Street, Byres Road, the Centre of Contemporary Arts, and outside the city in St. Andrews and Aberdeen.

Before the period of online book retail in higher education, campus shops cultivated close relations with lecturers. The current practice of accurately obtaining titles and reading lists for forthcoming courses and in advance of semester start - beginning from, perhaps, May, June or sometimes as early as March for a start in September or October - stems from methods developed by Robert Clow in the 1950s, when the company made an active move to acquire reading lists for the students, something academics and publishers were not in the habit of supplying. A system of 
grading was introduced to identify whether the title was essential or just suggested reading, as this would determine the quantity ordered. The whole time-consuming process was supported by previous years' sales figures and staff knowledge of student requirements.

Bulk-buying and customized or bundled titles allowed the shops to negotiate discounts with academic publishers, all predicated, however, on accurate reading lists. Several of the JS managers who were interviewed claimed a direct correlation between holes in planned spending for a particular course and lack of lecturer contact. Relations with lecturers, therefore, were and still are crucial - to the point of being a distinguishing feature of academic bookselling in that the student is joined by the academic among the agents making the purchasing decision.

In bookselling to higher education, what may appear to be a fairly straightforward process of buying and selling stock is really a specialist and complex form of retail. First, there is the need for knowledge of regular customer reading habits, combined with a need for product knowledge among staff, simply to answer standard customer queries. Second, there are number of suppliers. Where supermarkets may handle thousands of products, they deal with, perhaps, ten suppliers. JS bookshops, on the other hand, have to deal with in excess of 100 suppliers, each with particular ways of handling orders, sales and invoicing. A huge back-office process is created, both at the shop and at the head office. This situation is made doubly complex since unsold books can be returned to the publisher, a time-consuming process requiring manual checking of stock (one of the key downfalls for a bookseller is having capital tied up in slow-moving stock). Within the higher education market for books, the length of a particular course determines the shelf life of a book, often around two to three months. This means that cash tied up in stock for, say, the first semester has to be freed, by returning the books, to allow the purchase of second-semester stock.

In higher education, an effect of the liberalization of the later 1990s was to disrupt previous relationships, between students, lecturers and the campus bookstore, that had been built up for 
almost a century. With online resources, students could access tutor-recommended titles themselves, often finding arguably less-suitable alternatives - in principle, good for the students' pocket - but it weakened the guidance derived from lecturers and meant that campus bookstores could no longer rely on sales figures required for their bulk-buying practices. Such liberalization helped accelerate the deteriorating infrastructure of on-campus bookstores, and meant that academic book retail changed profoundly, where stationery and even cigarettes could become important lines. During an interview with JS CEO Peter Gray, an estimate was made of the proportion of sales for books relative to other products and services. For the period 2006 to 2008, it was found that around 60 per cent of JS sales at the University of the West of Scotland was no longer related to books (Gray 2015).

\section{The move to ASPIRE}

A key event came with the experience of JS in sub-Saharan Africa: an area where JS still has interests. In 2001, John Smith's opened Books Botswana, a former Coutts shop, on the University of Botswana campus in Gaborone as a response to State and University difficulties in supplying books and academic materials to students. ${ }^{5}$ Previously, State-funded Botswana students had extreme difficulties in obtaining course books through the existing uncoordinated multiple distribution channels. Although the State was happy to pay for the books, the fragmented supply process, from gathering reading lists from lecturers, through procurement from publishers, to students having books in hand, meant that books were arriving only well after semester start. Associated frustrations were linked to student riots, and procurement became a political problem. JS became involved by undertaking to coordinate the university's entire book supply. By reducing the intermediation in the supply chain and engaging in mass procurement, JS were able to deliver the right books on time. A solution - in this case, an academic book delivery system - that was 
assisting a democratic State-funded educational project on behalf of the Botswanan people had been brought to fruition by limiting the radical liberalization and ineffectiveness of the former system: again, an enabling through regulating commercial structures of something genuinely progressive.

By contrast, free higher education was dismantled and then removed in England under a series of targeted Labour and Conservative-Liberal coalition Government policies to introduce tuition fees: chiefly in two tranches, in 2004 and in 2010, where caps on fees were set at $£ 3000$ and $£ 9000$, respectively. One of the concessions that government rebels managed to push through in 2004 was a $£ 300$ bursary to be paid back to the poorest students (Smith and Alley 2004). This and other such bursaries were intended to mitigate the exclusory effects of fee-paying education, and, depending on region and institution, bursaries might include reductions to fees or maintenance allowances, funded-access to teaching materials, or cash paid back directly to the student. Then as now, the raft of bursaries available, accessible through each HEI's access agreement, gather around desires to combat barriers to education that fee-paying introduced. Public bodies such as OFFA have been set up to safeguard fair access. Whether the aims expressed through bursaries are genuine or a tactic to assuage critics of fee-paying is a political question not addressed in this or the companion report. While fee-paying is not a feature of Scottish higher education, what remains clear for England is that the various bursary systems have the potential, at least, to widen opportunities in current conditions and ensure that the student experience is one of effective learning.

The central question then becomes what sort of bursaries lead to effective learning? Providing students with cash bursaries may make them responsible for their own futures and they will certainly learn from the experience; but will the learning take place on a degree programme or later, looking back at wasted funds? An alternative would be to organize the bursary around the supply of academic materials, which is the argument by which JS were able to adapt their business 
in a new set of historical conditions, most notably in the scheme ASPIRE. The current operations around ASPIRE are the subject of the report to which this current article is a companion.

Overall, as this historical companion piece has hoped to demonstrate, the trajectory along which JS has travelled since eighteenth-century Glasgow has three constant features: the first, the ability of JS to adapt to new conditions; the second, that the conditions comprise a constant exchange between diversification and consolidation in response to periods of liberalization and regulation; and the third, the inseparability of two strategic principles - economic viability and the enduring belief that readers and retailers both benefit from access to good books.

\section{References}

Anon. (1906), The Successful Bookseller: A Complete Guide to Success to all Engaged in a Retail Bookselling, Stationery, and Fancy Goods, London: Successful Bookseller Publishing Company.

(1994), 'Chapters in a lifetime', The Herald, Scotland, 29 April, http://www.heraldscotland.com/news/12674402.Chapters_in_a_lifetime/. Accessed 01 August 2015.

Bradley, Sue (ed.) (2008), The British Book Trade: An Oral History, London: The British Library.

Brown, S. (2012), 'Reading the Scottish enlightenment: Books and their readers in Provincial Scotland 1750-1820 (review)', The Library: Transactions of the Bibliographical Society, 13:3, pp. $347-49$. 
Cleland, James (1829), The Annals of Glasgow Comprising an Account of the Public Buildings, Charities, and the Progress of the City, Glasgow: John Smith \& Son.

Clow, Robert (1972), 'Gibson Street premises', handwritten note, 9 September (held by current coauthor Stephen Hall).

Colclough, Stephen (2004), "Purifying the sources of amusement and information": The railway book-stalls of W. H. Smith \& Son, 1855-1860', Publishing History, 56, pp. 27-51.

COSHEP (1999), Entrance Guide to Higher Education in Scotland, Cheltenham: Universities and Colleges Admissions Service and Committee of Scottish Higher Education Principals.

Eliot, Simon (1994), Some Patterns and Trends in British Publishing 1800-1919, London: The Bibliographical Society.

(2009), 'Fiction and non-fiction: One- and three-volume novels in some Mudie catalogues, 1857-94', Publishing History, 66, pp. 31-47.

Finkelstein, David (1993), 'The secret: British publishers and Mudie's struggle for economic survival 1861-1864', Publishing History, 34, pp. 21-50.

Gray, Peter (2015), interview in person, John Smith's head office, Ringwood, UK. 11 September. 
Griest, Guinevere (1965), ‘A Victorian leviathan: Mudie's select library', Nineteenth-Century Fiction, 20:2, pp. 103-26.

(1970), Mudie's Circulating Library and the Victorian Novel, Newton Abbot: David and Charles.

Hall, Stephen (2009), 'Historicising the Glasgow bookseller John Smith and Sons', M.Sc. dissertation, Edinburgh: University of Edinburgh.

Manley, K. A. (2012), Books, Borrowers, and Shareholders: Scottish Circulating and Subscription Libraries before 1825; A Survey and Listing, Edinburgh: Edinburgh Bibliographical Society.

McCleery, Alistair, Finkelstein, David and Jennie Renton, J. (eds) (2009), An Honest Trade: Booksellers and Bookselling in Scotland, Edinburgh: John Donald.

Mumby, Frank and Norrie, Ian (1974), Publishing and Bookselling, 5th rev. ed., London: Jonathan Cape.

Smith, John and Son (1908), John Smith and Son's Educational Guide, Comprising Prospectuses of Various Public and Private Educational Institutions (1908-1909), 39th ed., Glasgow: John Smith and Son (1925), A Short Note on a Long History 1751-1925, Glasgow: John Smith and Son. 
Smith, Mat and Alley, Stuart (2004), 'Timeline: Tuition fees', The Guardian, 27 January, http://www.theguardian.com/education/2004/jan/27/tuitionfees.students. Accessed 01 July 2015.

\section{Contributor details}

With a Ph.D. from Aarhus, Denmark, Simon Frost is Senior Lecturer in English at Bournemouth University, Senior Editor for Oxford University Press (Oxford Research Encyclopedia [ORE]), and Director of Transnational Affairs and Executive Board member of the Society for the History of Authorship, Reading and Publishing (SHARP). He is the author of Business of a Novel: Economics, Aesthetics and the Case of Middlemarch (Pickering and Chatto, 2012), of numerous articles on the material text, including 'Economising in public', in Book History, Volume 17 (Johns Hopkins, 2014), and is co-editor of Moveable Type, Mobile Nations: Interactions in Transnational Book History (Museum Tusculanums Forlag, 2010). He is currently working on Private Gains and Retailed Literature, working with book retailers and using empirical research to create a theory of political reading within the frame of economics.

Contact:

Weymouth House W314, Talbot Campus, Bournemouth University, Fern Barrow, Poole, BH12 5BB, United Kingdom.

E-mail: sfrost@bournemouth.ac.uk

Stephen Hall (MSc [Edin], CBiol, MRSB) has had a varied career, working as a biologist, an academic bookshop manager, and archivist. He left academic bookselling to pursue further studies, obtaining an M.Sc. in Material Culture and the History of the Book from the University of 
Edinburgh. He has continued his studies and is currently involved in Ph.D. research at the University of Glasgow, on 'John Smith youngest, his world and the book trade of Glasgow 1800$1849^{\prime}$

For a short while Stephen was editor for The Kelvingrove Review published through the University of Glasgow. He wrote the introductory chapter for the Coming to Scotland: The African Pioneers and Their Stories, and has copy-edited and designed several publications for the Next Step Initiative and the African Forum Scotland charities. He has co-authored with Rosemary Sleith the Annual Scottish African International Business Conference \& Exhibition Report (2013) for the African Forum Scotland.

Additionally, he was a project assistant for the Cullen Project at the University of Glasgow and is currently a transcriber for the Livingstone Online Enrichment and Access Project through Queen's University Belfast. Part time he is the Museum Heritage and Development Manager for the Inclusive Museum Heritage Project, funded by the Heritage Lottery Fund.

E-mail: stephen.hall@macace.net

Notes

\footnotetext{
${ }^{1}$ The best historical source for JS is Hall (2009), which in turn draws on John Smith and Son (1925). Stephen Hall is a former manager of John Smith's, who has preserved much of the extant JS archive material. Unless otherwise stated, historical data are taken from Hall (2009), and this companion piece is much indebted to Hall's work. A good general source for book retail history is Mumby, F. and Norrie, I. (1974). More recent works on bookselling are Bradley (2008), and McCleery et al. (2009).
} 
${ }^{2}$ Unfortunately there is no good overall introduction to circulating libraries. Work dealing specifically with Mudie's includes Griest (1965, 1970), Finkelstein (1993) and Eliot (2009). For W. H. Smith's, see Colclough (2004). For Scottish circulating libraries, see Manley (2012).

${ }^{3}$ For Glaswegian religiosity see The Glasgow Story, http://www.theglasgowstory.com/story.php?id=TGSCC (accessed January 2015). Publication data, see Hall (2009: 65-9). See also Eliot (1994).

${ }^{4}$ No archived accounts are available for $1900-1908$, see John Smith \& Son, 'Balance sheet profit \& loss account as at 30 April 1899' (shops at Renfield and Ingram Streets); John Smith \& Son, 'Balance sheet and relative accounts 31 March 1909', prepared by Carson Moores and C. A. Watson, Glasgow (shops at Ingram and George Streets - no sales were recorded through Renfield Street shop as the stock was transferred to the other shops, but it still had furniture); John Smith \& Son, 'Balance sheet and relative accounts 31 March 1910', prepared by Carson Moores and C. A. Watson, Glasgow (shops at Ingram and George Streets).

${ }^{5}$ See http://www.johnsmithinternational.com/live/about-us/ (accessed January 2015), also Gray (2015). 